Article

\title{
A Fuzzy Multicriteria Group Decision Making Approach for Evaluating and Selecting Fintech Projects
}

\author{
Santoso Wibowo *(D), Lakshmi Grandhi, Srimannarayana Grandhi and Marilyn Wells (D)
}

Citation: Wibowo, S.; Grandhi, L.; Grandhi, S.; Wells, M. A Fuzzy Multicriteria Group Decision Making Approach for Evaluating and Selecting Fintech Projects. Mathematics 2022, 10, 225. https:// doi.org/10.3390/math10020225

Academic Editor: Gia Sirbiladze

Received: 23 November 2021

Accepted: 10 January 2022

Published: 12 January 2022

Publisher's Note: MDPI stays neutral with regard to jurisdictional claims in published maps and institutional affiliations.

Copyright: (C) 2022 by the authors. Licensee MDPI, Basel, Switzerland. This article is an open access article distributed under the terms and conditions of the Creative Commons Attribution (CC BY) license (https:// creativecommons.org/licenses/by/ $4.0 /)$.
School of Engineering \& Technology, CQUniversity, Melbourne, VIC 3000, Australia; grandhi@cqu.edu.au (L.G.); s.grandhi@cqu.edu.au (S.G.); m.wells@cqu.edu.au (M.W.)

* Correspondence: s.wibowo1@cqu.edu.au

\begin{abstract}
The use of financial technologies (Fintech) has increased recently due to their support to financial institutions in managing their financial operations and achieving competitive advantages. Even though there are several benefits with Fintech development and implementation, selecting the most suitable Fintech project can be complex. This is due to the involvement of numerous decision makers, the conflicting nature of multiple evaluation criteria, and fuzzy data derived from imprecise judgments of qualitative performance ratings. Interval-valued based intuitionistic fuzzy numbers are used to deal with the inherent vagueness and imprecision of the evaluation process. An algorithm based on an interval-valued intuitionistic fuzzy weighted geometric (IIFWG) and the concept of ideal solutions is developed. As a result, the most suitable Fintech project alternative can be selected across all evaluation criteria. To demonstrate the effectiveness of the approach, a Fintech project selection problem is presented.
\end{abstract}

Keywords: evaluation and selection; Fintech; multicriteria decision making; vagueness and imprecision; TOE model

\section{Introduction}

Fintech refers to the new technologies adopted by financial institutions such as banks for delivering financial services to their customers [1]. Traditionally, financial institutions have offered services to their clients under conventional terms. According to Azarenkova et al. [2], Fintech helps introduce financial innovations to transform the financial system for productivity gains. Some of the Fintech services include online banking, international money transfers, BPay, financial planning including investment planning loans, personal and home insurance, credit card approval and cheque deposits using smart devices $[3,4]$. All these involve minimal human intervention to offer accessibility and convenience to consumers, cost savings and profit growth for the organizations.

The term Fintech can be applied to any form of innovation involving automation of financial transactions and the use of cryptocurrencies such as Bitcoin and Ether [5]. Traditionally, Fintech is referred to as information technology used by financial institutions but now it includes a range of technologies that promote personal banking and microfinance [1] Over the last few decades, financial institutions are actively pursuing benefits from new technologies [2]. In fact, Fintech has become the focal point for both the financial industry and academia. Gabor and Brooks [6] explain that investments in Fintech have reached more than US\$20 billion. Between 2010 and 2016, global Fintech investments reached more than US\$150 billion, which is a 12-fold increase. By the end of 2016, the number of Fintech companies increased to 2000 and the investments in these organizations also passed US\$20 billion [6]. These figures suggest the increased use of Fintech in the finance sector.

Fintech offers enormous benefits including the provision of financial services to unserved and underserved populations [1]. Azarenkova et al. [2] and Mention [1] point out that internet accessibility and the use of mobile devices by consumers have contributed to 
Fintech's growth in recent years. The motivations for the adoption of Fintech are humanrelated because it allows consumers to interact with banks while minimizing the need to interact with staff when conducting financial transactions. This shows the use of Fintech not only by organizations in the finance sector for delivering services but also by consumers for accessing banking services [7]. From the financial industry perspective, the use of Fintech is critical for delivering innovative services to their customers and achieving competitiveness $[1,2,4]$.

Much research has been conducted on the development of robust methods for selecting Fintech projects [8-10]. For example, $\mathrm{Mu}$ and Lee [8] present the integrated approach based on fuzzy analytic hierarchy process (FAHP) and the technique for order preference by similarity to ideal solution (TOPSIS) for evaluating and selecting Fintech third-party payment systems. Fintech projects are evaluated on the basis of the determined criteria. The relative weight of each criterion is calculated using TOPSIS. The TOPSIS approach involves defining a closeness coefficient to work out the ranking order of available Fintech projects. $\mathrm{Xu}$ [9] applies the AHP approach to identify the most suitable Fintech project for development and implementation. The AHP is used to obtain the relative priority of the different criteria in terms of flexibility and to assess the alternatives. Gang et al. [10] apply the TOPSIS approach for selection of Fintech projects. The use of linguistic terms is an efficient way of assessing the weights of the selected criteria and the performance of every alternative in relation to each criterion. A coefficient is introduced for describing the overall performance of all Fintech projects along with the ideal solution concept. These approaches are found to be useful for dealing with the project selection problem. However, these approaches suffer from several limitations including (a) inability to handle multiple evaluation criteria, (b) inadequate modeling of the subjectiveness and imprecision of the human decision process and (c) the cognitive demand on decision makers in the evaluation process. Therefore, it is important to develop a structured approach capable of comprehensively evaluating the overall performance of available Fintech projects in a specific situation.

We present a fuzzy multicriteria group decision making approach to assess the performance of Fintech projects. Interval-valued based intuitionistic fuzzy numbers are used to deal with the inherent vagueness and imprecision of the performance evaluation process. An algorithm based on an interval-valued intuitionistic fuzzy weighted geometric (IIFWG) and the concept of ideal solutions is developed to deal with multiple decision makers assessments. As a result, the most suitable Fintech project alternative can be selected across all evaluation criteria. A Fintech project selection problem is presented to demonstrate the effectiveness of the approach.

In what follows, Section 2 presents a literature review on Fintech. Section 3 presents the discussion of relevant criteria for evaluating the performance of Fintech projects. Section 4 presents the fuzzy multicriteria group decision making approach. This is followed by an example to illustrate the usefulness of the proposed method in order to address the Fintech project evaluation and selection problem.

\section{Literature Review}

Information technology has transformed the way data is being collected and processed. The literature highlights the impact of digitization on the financial services sector. Puschmann [11] explains that most financial products are service products and based on information. The use of technology in the finance industry is not new. For example, automated telling machines (ATM) and international money transfers (wire transfers) have been in use for a very long time. Recently, there has been a growing interest among academics and industry practitioners in Fintech. Goldstein et al. [12] report that scholars in educational institutions from USA, Australia, Canada, China, Germany, India, Italy and UK are researching the benefits and challenges of Fintech.

Fintech is acting as a catalyst in transforming traditional ways of banking [12,13]. Some of the Fintech products include peer-to-peer lending, small business finance, robot advice, 
digital banking, cryptocurrency and e-wallets [14]. Recent studies [11,12,15] highlight the importance of fintech to the finance sector. Due to these benefits, banks, insurance and non-banking companies are providing customer-oriented business to consumer, consumer to consumer and business to business Fintech-based solutions [11]. Fintech offers several benefits to both financial organizations and their consumers. From a financial organizational point of view, FinTech allows digital accounts and payments to speed up transaction time and reduce cost on transactions. It improves security, reduces errors and helps to combat fraud [14]. A review by the Treasury of the Australian Government suggests that small and medium-sized enterprises (SMEs) are critical for economic growth and employment. However, some SMEs struggle to manage their finances. With Fintech, it would be possible to offer efficient and effective solutions to SMEs. These solutions include peer-to-peer lending, merchant finance and online trade finance [16]. From a consumer point of view, Fintech allows access to financial products and services, lower cost of services, anytimeanywhere access via mobile devices, and access to financial data to control finances and improve efficiency and the customer experience [11].

Fintech offers benefits to both financial organizations and consumers. However, several challenges have slowed Fintech adoption rates. First, data security is one of the major concerns in the public network. Fintech presents opportunities to offer mobile banking services through mobile applications. Lack of sufficient authentication mechanisms may lead to opening back doors for hackers and the stealing of sensitive data [17].

Second, the finance industry is a highly regulated industry [18]. Failure to abide by government regulations may lead to severe penalties. To ensure legal compliance, there is a need to balance Fintech innovations with government regulations [19]. Third, banks collect and store customers' transactional data frequently. Analyzing this big data can help understand customers' needs and maintain a competitive advantage. Integrating big data with artificial intelligence (AI) can help successfully analyze the data and find hidden patterns, but the challenge is to identify the right tools and implement these with expert teams [20]. Fourth, banks are at the forefront in adopting and using technologies. Previous studies indicate the presence of several legacy systems. Adopting new technologies and integrating new technologies can be complex and challenging [17]. Besides these challenges, there is a need to offer personalized services to customers. Presenting various options to customers will help improve customer retention rates and customer loyalty [21].

\section{Criteria for Evaluating the Performance of Fintech Projects}

It is important to identify the relevant criteria for evaluating the performance of the available Fintech projects. Over the years, scholars have presented various models to illustrate the underlying causes for adopting new technologies. Some of these models include theory of reasoned action (TRA), theory of planned behaviour (TPB), technology acceptance model (TAM), social cognitive theory (SCT), diffusion of innovation (DOI), unified theory of acceptance and use of technology (UTAUT) and the technology, organization and environment model (TOE) [22]. Of these models, the TOE model has gained importance as it offers a solid theoretical basis for technology adoption intention [23].

The TOE model, proposed by Tornatzky and Fleischer [24], presents common factors to predict technology adoption intention. This model presents three different contexts, technology, organization and environment. The majority of the adoption models including TRA, TPB and TAM are built on the belief that technology determines an organization's structure and an individual's technology adoption intention. However, the TOE model brings three (technology, organization and environment) different contexts together to include both human and non-human factors, which was not possible with the earlier (TRA, TPB, TAM and UTAUT) models [25]. Moreover, it provides a holistic view of the factors associated with technology adoption. As a result, the TOE model has been used in various technology adoption studies including e-commerce, enterprise resource planning, e-procurement and knowledge management systems [23]. 
The TOE model's ability to consider the role of technology, organization and environment in technology adoption intention has been thoroughly tested in different contexts [26,27]. Based on empirical evidence and a comprehensive review of the technology adoption literature, three dimensions and twelve criteria are selected for evaluating the performance of Fintech projects. The three dimensions are: (a) technology, (b) organization and (c) environment.

\subsection{Technology}

The technology context considers both internal and external technologies that have direct association with the organization. The technology domain consists of innovation variables from the Diffusion of Innovation (DOI) theory [28]. Over the years, researchers have included several other factors including compatibility, triability, relative advantage (indirect and direct) and complexity [26,29-33]. Of these, relative advantage, compatibility and complexity are considered the most relevant and were adopted by Gholami et al. [27] in their studies. Their results highlight the significance of technology variables in technology adoption. The relative advantage of new technologies [34], compatibility [35] and complexity [36] are the technology-related factors that would determine organizations intention to adopt new technologies.

\subsubsection{Relative Advantage}

Relative advantage refers to the evaluation of technical factors concerning the benefits provided by the technology. It is considered a motivational factor for decision-makers when deciding on the adoption of new technologies [28,37]. Relative advantage is often associated with economic value and the benefits of a particular technology. Fintech has unique characteristics such as on-demand and anytime-anywhere access to allow users to self-serve. This study considers that the relative advantage of Fintech will improve the quality of a work environment by allowing users to complete their tasks more quickly at high quality with efficiency, which in turn may lead to its adoption.

\subsubsection{Compatibility}

Compatibility is the extent to which the technology meets a user's expectations [38]. Rogers [28] explains that compatibility identifies whether the new technology is in line with the current practices. With Fintech, the 'compatibility' factor helps to identify the relevance of technology in the financial sector and its alignment with financial institutions. Earlier studies highlight that compatibility can act as a measure of usefulness and how well the technology supports potential users. In essence, the compatibility factor may help assess the suitability of Fintech in the organization [23].

\subsubsection{Complexity}

Complexity is an individual's perception of difficulty in learning and using new technology [23]. Bruneel et al. [39] explain that high-technology complexity may lead to potential opportunistic behaviour. Earlier studies point out that higher complexity in using the technology can lead to users avoiding interaction with the technology [40]. Hence, complexity is considered an important issue in technology adoption studies [39]. Moreover, it can be argued that lower technological complexity may influence users to trust and use the technology.

\subsection{Organization}

The organization domain considers descriptive measures such as organization size, top management support and organizational competencies [26,27]. A study into the determining factors in mobile technology-based services adoption by librarians found that organization factors have positively influenced technology adoption in the University of Tabriz in Iran [27]. The descriptive measures showed a positive impact on technology adoption. The environmental context refers to the environment in which an organization 
conducts its business [25]. Support from senior management, organization size and organizational competency are considered to be the key factors in the organization domain [41].

\subsubsection{Top Management Support}

This is the degree to which the senior management team understands the value of Fintech and the extent the senior management team is involved in the adoption process [42]. The senior management team plays a vital role in supporting the project and providing wide coverage of the possible benefits of the proposed technology and aligning it with the organization's goals [27]. Top management support may influence users to trust new technologies, because of the active role they play in ensuring the successful adoption of new technologies [43] such as Fintech and their commitment to addressing issues that may arise due to the adoption of new technologies [42].

\subsubsection{Organization Size}

Organization size is generally considered an important indicator of the resources an organization holds. The impact of organization size on trust in new technologies and subsequent adoption has been considered an important factor in technology adoption studies [44]. Fintechs are being adopted by larger organizations because of the costs associated with acquiring, implementing and managing the systems. Therefore, it can be argued that Fintechs would generally be implemented by larger organizations compared to smaller organizations. As organization size may act as an indicator for technology readiness, potential technology users may be inclined to use new technologies because the organization has enough resources to absorb potential risk [45].

\subsubsection{Organizational Readiness}

Organizational readiness is the preparedness and capacity to invest, adopt and manage new technologies. Dabholkar [46] explains that there is a positive relationship between an individual's control beliefs and their technology adoption intention. In essence, individuals' comfort can be linked to their beliefs, such as safety concerns and negative outcomes of technologies. Moreover, an organization's capability can influence individuals' control beliefs, which may, in turn, influence their acceptance of new technologies [37].

\subsection{Environment}

The environment domain focuses on the environmental aspects in which the organization conducts its business. It includes factors such as government regulation, competition and vendor support because these factors are proven to influence organizations' technology adoption intention [47].

\subsubsection{Government Regulation}

Government regulation encompasses the benefits and support provided by the government and its regulatory bodies [48]. This concerns how an organization conducts their business operations in line with government regulations by giving priority to external factors that would influence the industry. [49]. Salwani et al. [49] explain that the lack of appropriate policies and regulatory frameworks by governments may result in opportunistic behaviour, which may, in turn, discourage individuals to trust new technologies. Empirical evidence suggests that government regulation has shown a positive impact on users' technology adoption intention, as it motivates users to trust the technology [41].

\subsubsection{Competition}

Competition in the industry may force organizations to mimic their competitors [50]. Scholars point out that competition may positively influence technology adoption intention because top management may perceive that new technology would allow them to compete more effectively [45]. According to Tornatzky and Fleischer [24], environmental factors define an organization's strategies and its propensity to compete in the market. 
Awa et al. [25] suggest that organizations would be inclined to adopt new technologies in a competitive environment. However, late adopters may not achieve the same advantage as early adopters of technology, but it offers them confidence in potential technology [51], which may lead to adopting and using new technologies such as Fintech.

\subsubsection{Vendor Support}

Fintechs are adopted by organizations in the finance sector to offer flexibility to their customer and allow them to conduct financial transactions online [1]. Regardless of the money involved in transactions, organizations are obliged to manage transactions in an efficient manner [2,52]. Failure to ensure system availability may force users to seek alternatives. Under these conditions, vendor support becomes critical in ensuring continuity in providing services through Fintech [53]. While the technology adopting organization manages the technology at its location, vendors may offer support as per the agreed terms and conditions. Poor service from vendors in fixing problems and long financial system downtimes may influence users' trust in technologies [2,54].

\section{Multicriteria Group Decision Making under Interval-Valued Intuitionistic Fuzzy Environment}

A multicriteria group decision making problem usually includes a number of alternatives $A_{i}(i=1,2, \ldots, n)$ with respect to each criterion $C_{i j}(i=1,2, \ldots, n ; j=1,2, \ldots, m)$, to be evaluated by multiple decision makers $D_{k}$. Decision makers often have to provide subjective assessments for determining the performance of the available alternatives with respect to each criterion and the relative importance of the criteria $[55,56]$.

Vagueness and imprecision are always present in the decision making process due to (a) incomplete information, (b) ambiguous information, and (c) subjective information [8]. To adequately model the vagueness and imprecision of the decision making process, intervalvalued based intuitionistic fuzzy numbers are used [57]. This is due to (a) effectiveness in dealing with the vagueness and imprecision, (b) simplicity for decision makers in assigning their subjective assessments in the form of membership degree and non-membership degree, and (c) efficiency in aggregating the decision makers' assessments [57].

Mathematically, the interval-valued intuitionistic fuzzy decision matrix for each decision maker can be defined as $R^{(k)}=\left(r_{i j}^{(k)}\right)_{m \times n}$, where $k=1,2, \ldots, s$ and $\left(r_{i j}^{(k)}\right)=$ $\left\{\left(\mu_{i j}^{L(k)}, \mu_{i j}^{U(k)}\right),\left(v_{i j}^{L(k)}, v_{i j}^{U(k)}\right)\right\}$ is an interval-valued intuitionistic fuzzy number which depicts the performance rating of alternatives with respect to all available criteria. $\left(\mu_{i j}^{L(k)}, \mu_{i j}^{U(k)}\right)$ represents the degree to which alternative $A_{i}$ satisfies criterion $C_{j}$, while $\left(v_{i j}^{L(k)}, v_{i j}^{U(k)}\right)$ represents the degree to which alternative $A_{i}$ dissatisfies criterion $C_{j}$. Here, $w=\left(w_{1}, w_{2}, \ldots, w_{m}\right)^{T}$ represents the weight of each decision maker and $\sum_{j=1}^{n} w_{j}=1$ and $w_{j} \in[0,1]$.

\section{The Fuzzy Multicriteria Group Decision Making Approach}

The performance evaluation process involved in Fintech projects is complex and challenging. This is due to (a) the involvement of numerous decision makers, (b) the conflicting nature of multiple evaluation criteria and (c) fuzzy data derived from imprecise judgments of qualitative performance ratings [55]. It is therefore desirable to develop a structured method capable of comprehensively evaluating the overall performance of available Fintech projects in a specific situation.

In this paper, the Fintech project performance evaluation problem with respect to the multiple evaluation criteria is formulated as a multicriteria group decision making problem.

The first stage is to obtain the performance ratings with respect to all available criteria from the decision makers. This is followed by applying the interval-valued intuitionistic 
fuzzy weighted geometric (IIFWG) operator [58] for aggregating individual fuzzy decision matrices into a collective interval-valued intuitionistic fuzzy decision matrix $r_{i j}$ as in (1).

$$
r_{i j}=\left(\left[\prod_{k=1}^{s}\left(a_{i j}\right)^{k}, \prod_{k=1}^{s}\left(b_{i j}\right)^{k}\right],\left[1-\prod_{k=1}^{s}\left(1-c_{i j}\right)^{k}, 1-\prod_{k=1}^{s}\left(1-d_{i j}\right)^{k}\right]\right)
$$

The concept of the ideal solutions is introduced for determining the best and worst decision outcomes in a given decision situation [55]. This concept has been widely used for dealing with practical decision problems due to its simplicity in concept, and its computation efficiency [56].

Here, the interval-valued intuitionistic fuzzy positive ideal solution $\alpha^{*}$ and the intervalvalued intuitionistic fuzzy negative ideal solution $\alpha^{-}$can be calculated as in (3) and (4) respectively.

$$
\begin{aligned}
\alpha^{*} & =\left(r_{1}^{+}, r_{2}^{+}, \ldots, r_{m}^{+}\right) \\
& =\left\{\left\langle\left(\max _{i}, r_{i j}^{*} \mid j \in B\right),\left(\min _{i}, r_{i j}^{*} \mid j \in C\right)\right\rangle i=1,2, \ldots, n\right\} \\
\alpha^{-} & =\left(r_{1}^{-}, r_{2}^{-}, \ldots, r_{m}^{-}\right) \\
& =\left\{\left\langle\left(\max _{i}, r_{i j}^{*} \mid j \in B\right),\left(\min _{i}, r_{i j}^{*} \mid j \in C\right)\right\rangle i=1,2, \ldots, n\right\}
\end{aligned}
$$

where $B$ and $C$ are the set of benefit and cost criteria, $r_{j}^{+}=\left[\left(\mu_{j}^{L+}, \mu_{j}^{U+}\right),\left(v_{j}^{L+}, v_{j}^{U+}\right)\right]$ and $r_{j}^{-}=\left[\left(\mu_{j}^{L-}, \mu_{j}^{U-}\right),\left(v_{j}^{L-}, v_{j}^{U-}\right)\right]$.

The distance between alternative $A_{i}$ and the positive ideal solution $S_{i}^{+}$and the negative solution $S_{i}^{-}$can then be calculated respectively as in (4) and (5).

$$
\begin{aligned}
& S_{i}^{+}=\sqrt[p]{\frac{1}{4(t+1)^{p}} \sum_{j=1}^{n} w_{j}\left\langle\begin{array}{r}
\left|t\left(\mu_{i j}^{L}-\mu_{j}^{L+}\right)-\left(v_{i j}^{L}-v_{j}^{L+}\right)\right|^{p}+\left|t\left(v_{i j}^{L}-v_{j}^{L+}\right)-\left(\mu_{i j}^{L}-\mu_{j}^{L+}\right)\right|^{p} \\
+\left|t\left(\mu_{i j}^{U}-\mu_{j}^{U+}\right)-\left(v_{i j}^{U}-v_{j}^{U+}\right)\right|^{p}+\left|t\left(v_{i j}^{U}-v_{j}^{U+}\right)-\left(\mu_{i j}^{U}-\mu_{j}^{U+}\right)\right|^{p}
\end{array}\right.} \\
& S_{i}^{-}=\sqrt[p]{\frac{1}{4(t+1)^{p}} \sum w_{j}\left\langle\begin{array}{c}
\left|t\left(\mu_{i j}^{L}-\mu_{j}^{L-}\right)-\left(v_{i j}^{L}-v_{j}^{L-}\right)\right|^{p}+\left|t\left(v_{i j}^{L}-v_{j}^{L-}\right)-\left(\mu_{i j}^{L}-\mu_{j}^{L-}\right)\right|^{p} \\
+\left|t\left(\mu_{i j}^{U}-\mu_{j}^{U-}\right)-\left(v_{i j}^{U}-v_{j}^{U-}\right)\right|^{p}+\left|t\left(v_{i j}^{U}-v_{j}^{U-}\right)-\left(\mu_{i j}^{U}-\mu_{j}^{U-}\right)\right|^{p}
\end{array}\right\rangle}
\end{aligned}
$$

The closeness coefficient $C C_{i}$ determines the ranking order of each alternative. This can be calculated by (6).

$$
C C_{i}=\frac{S_{i}^{-}}{S_{i}^{+}+S_{i}^{-}}, i=1,2, \ldots, n
$$

Finally, the ranking order of each alternative $A_{i}$ based on the closeness coefficient $C C_{i}$ can be obtained. This shows that the underlying concept in the developed fuzzy multicriteria group decision making approach is simple and comprehensible. follows:

The fuzzy multicriteria group decision making procedure can be summarized as Step 1: Obtain the performance ratings with respect to all available criteria from the decision makers.

Step 2: Compute individual fuzzy decision matrices into a collective interval-valued intuitionistic fuzzy decision matrix as in (1).

Step 3: Calculate the interval-valued intuitionistic fuzzy positive and negative ideal solutions as in (2) and (3), respectively.

Step 4: Calculate the distance between alternative $A_{i}$, and the positive and negative ideal solution by using (4) and (5), respectively.

Step 5: Calculate the closeness coefficient $C C_{i}$ by using (6). 
Step 6: Determine the ranking order of each alternative $A_{i}$ based on the closeness coefficient $\mathrm{CC}_{i}$.

\section{An Example}

To demonstrate the applicability of the proposed fuzzy-based multicriteria group decision-making approach, we present a case study for evaluating the performance of Fintech project alternatives for a public-sector bank in India.

With a population of 1.3 billion people and a GDP of US\$10.5 Trillion, India has emerged as the fifth largest economy [59]. The major contributor to India's GDP is the services sector. Its contribution is estimated to be 54.7 per cent. Within the services sector, financial and real estate services account for 20.1 per cent [60]. The Indian financial services sector includes banks, insurance companies, mutual funds, financial intermediaries and non-banking finance companies. The total employment in the Indian finance sector is estimated to be around 4.5 million [61]. By the end of 2018, the Indian alternative finance market was valued at US\$ 547M. The alternative finance includes financial activity processes, financial channels and instruments which have emerged outside the traditional finance system. Some examples include crowdfunding, equity funding, peer-to-peer lending, cryptocurrencies and community shares [60].

According to the Reserve Bank of India, the local finance sector is well-regulated. Banks within the finance sector contribute significantly to India's economic growth. By the end of 2020, there are more than 96,000 banks with total assets worth US\$1.52 trillion. As banks are proven to play an important role in the country's economy, there is significant spending on infrastructure and technology adoption in this sector [62].

Banks in India are classified into commercial banks, small finance banks, payment banks and co-operative banks. By the end of 2020, there are 12 public-sector banks under the commercial banks' category and the Indian government holds more than a $50 \%$ stake. Of these public-sector banks, the State Bank of India (SBI) is ranked 1 with 420 million customers, US\$640b assets and US\$51b revenues. A recent report 'Tech Disruption in Retail Banking' suggests that SBI is well placed to deal with technology disruptions [63]. To maintain their presence in multi-channel platforms and facilitate banking as per customers needs, SBI introduced India's first digital services platform. The bank acknowledges the potential of new technologies such as artificial intelligence (AI), machine learning, blockchain and the internet of things. In line with motivation to adopt new technologies, it invests about Rs. 3500 crores each year [64]. Adopting Fintech will help Indian banks to offer a range of financial services not only to the metropolitan population but also to the rural population [65]. There are thousands of financial institutions in India, but the majority are still behind in adopting Fintech to provide online services to their customers.

With over 200 years of presence in India, SBI has more than 22,000 branches in India and 229 offices in 31 foreign countries. Besides banking services, it offers insurance and mutual fund products. It aims to provide simple, responsive and innovative financial solutions [66]. Based on a comprehensive review, three Fintech tools are identified to support the bank's goal to offer innovative financial solutions. They are Avaloq Banking Suite, Sopra Banking Platform, and Fenergo Client Lifecycle Management [67-69].

With a vision to reinvent finance for the people and make a difference in society, a Swiss-based company Avaloq offers core banking software. It has more than 150 clients in 30 countries and 2400 employees representing 65 nationalities. Its clients include Maybank, Barclays, BLKB, BZ Bank, Capitol Union Bank, CIMB, CFG Bank, HSBC and China Citic Bank International. Avaloq Banking Suite consists of a broad range of functionalities to address banking needs such as wealth management. It was successfully implemented at Maybank in 2019 to provide a better customer experience and has proven to support banks by offering client-centric services [67].

Founded in 1968, Sopra Banking Software employs more than 5000 experts globally. It has more than 1500 clients worldwide in 80 countries and delivered over 200 projects. Its customers include ING bank, Santander, Sprda-bank and Fidor Bank. Through its Sopra 
Banking Platform, Sopra Banking offers cloud-based ready-to-use solutions. It provides a seamless customer experience across mobile and web applications [68].

An Ireland-based Fintech company Fenergo offers cloud (SaaS) or on-premises technology solutions to over 80 of the world's top financial companies. Its clients include Bank of China, Westpac, National Australia Bank, Scotiabank, Bank of California and PNC Bank. Its Client Lifecycle Management (CLM) product gained popularity for helping banks to meet the anti-money laundering (AML) requirement and the recent guidelines on know your customer (KYC). Fenergo uses use artificial intelligence to analyze unstructured data to meet KYC and AML requirements. The CLM suite empowers clients to self-serve, integrates with data providers, enables real-time extraction of data from various documents, allows banks to onboard clients electronically in line with regulatory guidance and helps comply with local and global regulations [69].

The Fintech project performance evaluation process starts with forming a committee with five experts involved in the decision making process. Three evaluation criteria are identified for evaluating the performance of Fintech projects which include Technology $\left(C_{1}\right)$, Organization $\left(C_{2}\right)$, and Environment $\left(C_{3}\right)$. Three Fintech projects namely Avaloq Banking Suite $\left(A_{1}\right)$, (b) Sopra Banking Platform $\left(A_{2}\right)$, and Fenergo Client Lifecycle Management $\left(A_{3}\right)$ are to be evaluated with respect to the multiple evaluation criteria.

Firstly, the performance ratings with respect to all available criteria are obtained from the decision makers as shown in Table 1.

Table 1. Interval-valued intuitionistic fuzzy decision matrix.

\begin{tabular}{ccccc}
\hline \multirow{2}{*}{ Alternatives } & Decision Makers & \multicolumn{1}{c}{ Criteria } & \\
\cline { 2 - 5 } & & $C_{1}$ & $C_{\mathbf{2}}$ & $C_{\mathbf{3}}$ \\
\hline \multirow{2}{*}{$A_{1}$} & $D_{1}$ & $\{(0.4,0.6),(0.2,0.3)\}$ & $\{(0.4,0.5),(0.3,0.4)\}$ & $([0.3,0.5\},(0.1,0.2)\}$ \\
& $D_{2}$ & $\{(0.4,0.5),(0.1,0.3)\}$ & $\{(0.6,0.7),(0.1,0.2)\}$ & $(0.4,0.6\},(0.3,0.4)\}$ \\
& $D_{3}$ & $\{(0.5,0.7),(0.3,0.4)\}$ & $\{(0.5,0.6),(0.3,0.4])$ & $\{(0.2,0.5),(0.1,0.4)\}$ \\
& $D_{4}$ & $\{(0.4,0.7),(0.2,0.5)\}$ & $\{(0.4,0.7),(0.2,0.3)\}$ & $\{(0.6,0.7),(0.1,0.3)\}$ \\
& $D_{5}$ & $\{(0.6,0.8),(0.2,0.3)\}$ & $\{(0.6,0.7),(0.1,0.3)\}$ & $\{(0.5,0.6),(0.3,0.4)\}$ \\
& $D_{1}$ & $\{(0.3,0.5),(0.2,0.4)\}$ & $\{(0.3,0.5),(0.3,0.4)\}$ & $\{(0.5,0.7),(0.2,0.5)\}$ \\
$A_{2}$ & $D_{2}$ & $\{(0.4,0.6),(0.1,0.3)\}$ & $\{(0.4,0.7),(0.1,0.2)\}$ & $\{(0.4,0.6),(0.1,0.4)\}$ \\
& $D_{3}$ & $\{(0.3,0.5),(0.1,0.2)\}$ & $\{(0.4,0.5),(0.2,0.3)\}$ & $\{(0.5,0.8),(0.1,0.3)\}$ \\
& $D_{4}$ & $\{(0.6,0.8),(0.4,0.7)\}$ & $\{(0.6,0.8),(0.1,0.3)\}$ & $\{(0.5,0.6),(0.3,0.4)\}$ \\
& $D_{5}$ & $\{(0.4,0.7),(0.2,0.3)\}$ & $\{(0.4,0.7),(0.1,0.2)\}$ & $\{(0.4,0.6),(0.2,0.3)\}$ \\
& $D_{1}$ & $\{(0.5,0.8),(0.1,0.2)\}$ & $\{(0.5,0.6),(0.2,0.5)\}$ & $\{(0.6,0.9),(0.3,0.6)\}$ \\
& $D_{2}$ & $\{(0.6,0.8),(0.2,0.3)\}$ & $\{(0.6,0.7),(0.1,0.3)\}$ & $\{(0.5,0.6),(0.3,0.4)\}$ \\
& $D_{3}$ & $\{(0.4,0.7),(02,0.5)\}$ & $\{(0.4,0.8),(0.2,0.4)\}$ & $\{(0.5,0.8),(0.1,0.2)\}$ \\
& $D_{4}$ & $\{(0.4,0.7),(0.2,0.3)\}$ & $\{(0.4,0.7),(0.1,0.2)\}$ & $\{(0.6,0.7),(0.1,0.3)\}$ \\
& $D_{5}$ & $\{(0.5,0.8),(0.3,0.6)\}$ & $\{(0.6,0.8),(0.2,0.3)\}$ & $\{(0.5,0.7),(0.2,0.3)\}$ \\
\hline
\end{tabular}

By using (1), the aggregated interval-valued intuitionistic fuzzy decision matrix can be determined. The results are shown in Table 2.

Table 2. The aggregated interval-valued intuitionistic fuzzy decision matrix.

\begin{tabular}{cccc}
\hline \multirow{2}{*}{ Alternatives } & \multicolumn{3}{c}{ Criteria } \\
\cline { 2 - 4 } & $\boldsymbol{C}_{\mathbf{1}}$ & $\boldsymbol{C}_{\mathbf{2}}$ & $\boldsymbol{C}_{\mathbf{3}}$ \\
\hline$A_{1}$ & $\{(0.313,0.379),(0.224,0.283)\}$ & $\{(0.312,0.414),(0.219,0.227)\}$ & $\{(0.394,0.418),(0.157,0.257)\}$ \\
$A_{2}$ & $\{(0.659,0.714),(0.313,0.538)\}$ & $\{(0.571,0.719),(0.378,0.565)\}$ & $\{(0.562,0.668),(0.216,0.326)\}$ \\
$A_{3}$ & $\{(0.658,0.735),(0.249,0.431)\}$ & $\{(0.529,0.871),(0.241,0.473)\}$ & $\{(0.671,0.748),(0.314,0.422)\}$ \\
\hline
\end{tabular}

Based on (2) and (3), the interval-valued intuitionistic fuzzy positive ideal solution $\alpha^{*}$ and the interval-valued intuitionistic fuzzy negative ideal solution $\alpha^{-}$are calculated as shown in Table 3. 
Table 3. Interval-valued intuitionistic fuzzy positive and negative ideal solutions.

\begin{tabular}{cc}
\hline$\alpha^{*}$ & $\alpha^{-}$ \\
\hline$\{(0.537,0.764),(0.352,0.585)\}$ & $\{(0.637,0.719),(0.336,0.437)\}$ \\
$\{(0.648,0.679),(0.417,0.591)\}$ & $\{(0.542,0.644),(0.3126,0.476)\}$ \\
$\{(0.338,0.541),(0.227,0.419\}$ & $\{(0.586,0.761),(0.143,0.286)\}$ \\
\hline
\end{tabular}

The weighted separation measures between alternative $A_{i}$ and the positive ideal solution $S_{i}^{+}$and the negative solution $S_{i}^{-}$is calculated by using (4) and (5) respectively. Here, $w$ is taken as $\{0.25,0.25,0.20,0.15,0.15\}, p=1$, and $t=1$. Table 4 shows the results.

Table 4. The weighted separation measures between alternatives and ideal solutions.

\begin{tabular}{cc}
\hline$S_{i}^{+}$ & $S_{i}^{-}$ \\
\hline 0.129 & 0.217 \\
0.136 & 0.269 \\
0.121 & 0.316 \\
\hline
\end{tabular}

Finally, the closeness coefficient $C C_{i}$ values is computed by using (6). The results are shown in Table 5. Alternative $A_{3}$ is the most suitable Fintech project as it has the highest closeness coefficient value of 0.723 , as shown in Table 5.

Table 5. The closeness coefficient values of Fintech projects and their rankings.

\begin{tabular}{ccc}
\hline Alternatives & Closeness Coefficient & Ranking \\
\hline$A_{1}$ & 0.627 & 3 \\
$A_{2}$ & 0.664 & 2 \\
$A_{3}$ & 0.723 & 1 \\
\hline
\end{tabular}

To demonstrate the effectiveness of the fuzzy multicriteria group decision making algorithm, a comparative study is conducted with four other approaches [70-73]. These approaches are selected for this comparative study due to their ability to deal with multicriteria decision making problems under interval-valued intuitionistic fuzzy environments. Wang and Liu [70] propose the interval-valued intuitionistic fuzzy Einstein hybrid weighted geometric (IVIFHWG) operator for dealing with the interval-valued intuitionistic fuzzy numbers in multicriteria decision making problem. The limitation of their approach is that it is unable to deal with the group decision making process in an effective manner. Qi et al. [71] present a generalized cross-entropy measure to deal with multicriteria group decision making where criteria weights and expert weights are unknown under interval-valued intuitionistic fuzzy environments. An integrated algorithm based on the cross-entropy measure is developed for determining unknown expert weights. The approach is found to be computationally challenging and time consuming as it has to deal with the determination of unknown criteria and expert weights. Park et al. [72] apply the interval-valued intuitionistic fuzzy hybrid geometric (IIFHG) operator for dealing with the interval-valued intuitionistic fuzzy numbers in the multicriteria group decision making problem. The score function is introduced for calculating the score of each criterion and constructing the score matrix of the collective interval-valued intuitionistic fuzzy decision matrix. Then, an optimization model is developed for determining the weights of criteria. Based on the criteria weights and the interval-valued intuitionistic fuzzy weighted geometric (IIFWG) operator, the collective interval-valued intuitionistic fuzzy decision matrix can be obtained. This is followed by the determination of the overall interval-valued intuitionistic fuzzy values of alternatives, and then ranking of the alternatives based on the correlation coefficients between interval-valued intuitionistic fuzzy numbers. Their approach sometimes produces unreliable preference orders of alternatives [73]. Chen and Tsai [73] propose the use of the interval-valued intuitionistic fuzzy weighted geometric 
averaging (IVIFWGA) operator for dealing with the multicriteria decision making problem. However, the approach becomes cumbersome when multiple decision makers are involved.

The fuzzy multicriteria group decision making approach produces consistent results as compared to Wang and Liu's approach [70], Qi's approach [71], and Chen and Tsai's approach [73] as shown in Table 6. The fuzzy multicriteria group decision making approach is shown to be effective due to its simplicity and the comprehensibility of the underlying concept.

Table 6. Results of the Comparative Study.

\begin{tabular}{cc}
\hline Approaches & Ordering \\
\hline Wang and Liu [70] & $A_{3}>A_{2}>A_{1}$ \\
Qi et al. [71] & $A_{3}>A_{2}>A_{1}$ \\
Park et al. [72] & $A_{2}>A_{3}>A_{1}$ \\
Chen and Tsai [73] & $A_{3}>A_{2}>A_{1}$ \\
The proposed approach & $A_{3}>A_{2}>A_{1}$ \\
\hline
\end{tabular}

\section{Discussion and Conclusions}

The use of Fintech has increased recently due to its support to financial institutions in managing their financial operations and achieving competitive advantages. However, the selection of appropriate Fintech projects for development and implementation is complex.

This paper has presented a fuzzy multicriteria group decision making approach for evaluating and selecting Fintech projects for development and implementation. Intervalvalued based intuitionistic fuzzy numbers are introduced for dealing with the vagueness and imprecision of the evaluation process. An algorithm based on an interval-valued intuitionistic fuzzy weighted geometric (IIFWG) and the concept of ideal solutions are developed. As a result, the most suitable Fintech project alternative can be selected across all evaluation criteria. A Fintech project selection problem is presented to show the effectiveness of the approach.

The results showed that the fuzzy multicriteria group decision making approach can deal with the Fintech project selection problem in an effective manner due to the simplicity and comprehensibility of the underlying concept. It can be seen that the proposed fuzzy multicriteria group decision making approach produces the same results as Wang and Liu's approach [70], Qi et al.'s approach [71], and Chen and Tsai's approach [73].

The fuzzy multicriteria group decision making approach can be applied for dealing with the general multicriteria decision making problem in real situations. Future research in this area will consider a large number of criteria and alternatives in the evaluation and selection process. It may also focus on multicriteria group decision making, using multi-granularity linguistic term sets.

Author Contributions: Conceptualization, L.G.; methodology, S.W.; writing-original draft preparation, L.G.; writing-review and editing, S.W. and S.G.; supervision, S.W. and M.W. All authors have read and agreed to the published version of the manuscript.

Funding: This research received no external funding.

Institutional Review Board Statement: Not applicable.

Informed Consent Statement: Not applicable.

Data Availability Statement: Not applicable.

Conflicts of Interest: The authors declare no conflict of interest.

\section{References}

1. Mention, A. The future of Fintech. Res.-Technol. Manag. 2019, 62, 59-63. [CrossRef]

2. Azarenkova, G.; Shkodina, I.; Samorodov, B.; Babenko, M.; Onishchenko, I. The influence of financial technologies on the global financial system stability. Investig. Manag. Financ. Innov. 2018, 15, 229-238. [CrossRef] 
3. Ernst \& Young Global Limited. Global FinTech Adoption Index 2019; Ernst \& Young Global Limited: London, UK, 2019. Available online: https:/ / assets.ey.com/content/dam/ey-sites/ey-com/en_gl/topics/banking-and-capital-markets/ey-global-fintechadoption-index.pdf (accessed on 7 August 2020).

4. Wibowo, S.; Grandhi, L.; Grandhi, S. Multicriteria group decision making approach for evaluating the performance of FinTech projects. In Proceedings of the 15th IEEE Conference on Industrial Electronics and Applications (ICIEA 2020), Piscataway, NJ, USA, 9-13 November 2020; pp. 130-135.

5. Hu, Z.; Ding, S.; Li, S.; Chen, L.; Yang, S. Adoption intention of fintech services for bank users: An empirical examination with an extended technology acceptance model. Symmetry 2019, 11, 340. [CrossRef]

6. Gabor, D.; Brooks, S. The digital revolution in Financial Inclusion: International Development in the Fintech Era. New Polit. Econ. 2017, 22, 423-436. [CrossRef]

7. Zhao, Q.; Tsai, P.; Wang, J. Improving Financial Service Innovation Strategies for Enhancing China's Banking Industry Competitive Advantage during the Fintech Revolution: A Hybrid MCDM Model. Sustainability 2019, 11, 1419. [CrossRef]

8. $\mathrm{Mu}, \mathrm{H}$.; Lee, Y. An Application of Fuzzy AHP and TOPSIS Methodology for Ranking the Factors Influencing FinTech Adoption Intention: A Comparative Study of China and Korea. J. Serv. Res. Stud. 2017, 7, 51-68.

9. Xu, C. Using AHP-Entropy Approach to Investigate the Key Factors on FinTech Service. J. Comput. 2021, 32, $200-211$.

10. Gang, K.; Olgu, O.A.; Hasan, D.; Serhat, Y. Fintech investments in European banks: A hybrid IT2 fuzzy multidimensional decision-making approach. Financ. Innov. 2021, 7, 39.

11. Puschmann, T. Fintech. Bus. Inf. Syst. Eng. 2017, 59, 69-76. [CrossRef]

12. Goldstein, I.; Jiang, W.; Karolyi, G.A. To FinTech and Beyond. Rev. Financ. Stud. 2019, 32, 1647-1661. [CrossRef]

13. Wang, J.S. Exploring biometric identification in FinTech applications based on the modified TAM. Financ. Innov. 2021, 7, 42. [CrossRef]

14. Gai, K.; Qiu, M.; Sun, X. A survey on FinTech. J. Netw. Comput. Appl. 2019, 103, 262-273. [CrossRef]

15. Gopalan, S.; Jain, G.; Kalani, G.; Tan, J. Breakthrough IT banking. McKinsey Bus. Technol. 2012, 26, 30-35.

16. The Treasury. Economic Benefits of FinTech; Australian Government: Canberra, Australia, 2016. Available online: https://treasury. gov.au/publication/backing-australian-fintech/economic-benefits-of-fintech (accessed on 21 February 2021).

17. Lagna, A.; Ravishankar, M.N. Making the world a better place with fintech research. Inf. Syst. J. 2021, 32, 61-102. [CrossRef]

18. Bavoso, V. The promise and perils of alternative market-based finance: The case of P2P lending in the UK. J. Bank. Regul. 2019, 21, 395-409. [CrossRef]

19. Cooper, R.; Seddon, J.; van Vliet, B. High-frequency trading and conflict in the financial markets. J. Inf. Technol. 2017, 32, 270-282. [CrossRef]

20. Jocevski, M.; Ghezzi, A.; Arvidsson, N. Exploring the growth challenge of mobile payment platforms: A business model perspective. Electron. Commer. Res. Appl. 2020, 40, 100908. [CrossRef]

21. Suryono, R.R.; Budi, I.; Purwandari, B. Challenges and Trends of Financial Technology (Fintech): A Systematic Literature Review. Information 2020, 11, 590. [CrossRef]

22. Taherdoost, H. A review of technology acceptance and adoption models and theories. Procedia Manuf. 2018, $22,960-967$. [CrossRef]

23. Oliveira, T.; Martins, M.F. Literature review of information technology adoption models at firm level. Electron. J. Inf. Syst. Eval. 2011, 14, 110-121.

24. Tornatzky, L.; Fleischer, M. The Process of Technology Innovation; Lexington Books: Lexington, KY, USA, 1990.

25. Awa, H.O.; Ukoha, O.; Emecheta, B.C. Using T-O-E theoretical framework to study the adoption of ERP solution. Cogent Bus. Manag. 2016, 3, 1196571. [CrossRef]

26. Gangwar, H.; Date, H.; Raoot, A.D. Review on IT adoption: Insights from recent technologies. J. Enterp. Inf. 2013, 27, 488-502. [CrossRef]

27. Gholami, Z.; Abdekhoda, M.; Gavgani, V.Z. Determinant factors in adopting mobile technology-based services by academic librarians. J. Libr. Inf. Technol. 2018, 38, 271-277. [CrossRef]

28. Rogers, E.M. Diffusion of Innovations, 5th ed.; Free Press: New York, NY, USA, 2003.

29. Musawa, M.S.; Wahab, E. The adoption of electronic data interchange (EDI) technology by Nigerian SMEs: A conceptual framework. J. Bus. Manag. Econ. 2012, 3, 55-68.

30. Hossain, M.A.; Quaddus, M. The adoption and continued usage intention of RFID: An integrated framework. Inf. Technol. People 2011, 24, 236-256. [CrossRef]

31. Thiesse, F.; Staake, T.; Schmitt, P.; Fleisch, E. The rise of the 'next-generation barcode': An international RFID adoption study Supply Chain Manag. Int. J. 2011, 16, 328-345. [CrossRef]

32. Jang, S.H. An empirical study on the factors influencing RFID adoption and implementation. Manag. Rev. Int. J. 2010, 5, 55-73.

33. Wang, Y.M.; Wang, Y.S.; Yang, Y.F. Understanding the determinants of RFID adoption in the manufacturing industry. Technol. Forecast. Soc. Chang. 2010, 77, 803-815. [CrossRef]

34. Chiu, C.; Chen, S.; Chen, C. An Integrated Perspective of TOE Framework and Innovation Diffusion in Broadband Mobile Applications Adoption by Enterprises. Int. J. Manag. Econ. Soc. Sci. 2017, 6, 14-39.

35. Lian, J.W.; Yen, D.C.; Wang, Y.T. An exploratory study to understand the critical factors affecting the decision to adopt cloud computing in Taiwan hospital. Int. J. Inf. Manag. 2014, 34, 28-36. [CrossRef] 
36. Al-Jabri, I.M.; Sohail, M.S. Mobile banking adoption: Application of diffusion of innovation theory. J. Electron. Commer. Res. 2012, 13, 379-391.

37. Venkatesh, V.; Thong, J.; Xu, X. Consumer acceptance and use of information technology: Extending the unified theory of acceptance and use of technology. Manag. Inf. Syst. Q. 2012, 36, 157-178. [CrossRef]

38. Peng, R.; Xiong, L.; Yang, Z. Exploring tourist adoption of tourism mobile payment: An empirical analysis. J. Theor. Appl. Electron. Commer. Res. 2012, 7, 21-33. [CrossRef]

39. Bruneel, J.; Spithoven, A.; Clarysse, B. Interorganizational trust and technology complexity: Evidence for new technology-based firms. J. Small Bus. Manag. 2017, 55, 256-274. [CrossRef]

40. Hwang, B.-N.; Huang, C.-Y.; Wu, C.-H. A TOE approach to establish a green supply chain adoption decision model in the semiconductor industry. Sustainability 2016, 8, 168. [CrossRef]

41. Mahesh, D.D.; Vijayapala, S.; Dasanayaka, S.W.S.B. Factors affecting the intention to adopt big data technology: A study based on financial services industry of Sri Lanka. In Proceedings of the 2018 Moratuwa Engineering Research Conference (MERCon), Moratuwa, Sri Lanka, 30 May-1 June 2018.

42. AlHaderi, S.; Rahim, N.A.; Bmahros, H. Top Management Support Accelerates the Acceptance of Information Technology. Medwell J. 2018, 13, 175-189.

43. Kim, M.I.; Park, J.H. Identifying and prioritizing critical factors for promoting the implementation and usage of big data in healthcare. Inf. Dev. 2016, 33, 257-269. [CrossRef]

44. Hutchinson, K.; Donnell, L.V.; Gilmore, A.; Reid, A. Loyalty card adoption in SME retailers: The impact upon marketing management. Eur. J. Mark. 2015, 49, 467-490. [CrossRef]

45. Yoon, T.E.; George, J.F. Why aren't organizations adopting virtual worlds? Comput. Hum. Behav. 2013, 29, 772-790. [CrossRef]

46. Dabholkar, P.A. Consumer evaluations of new technology-based self-service options: An investigation of alternative models of service quality. Int. J. Res. Mark. 1996, 13, 29-51. [CrossRef]

47. Dahnil, M.I.; Marzuki, K.M.; Langgat, J.; Fabeil, N.F. Factors influencing SMEs adoption of social media marketing. Procedia-Soc. Behav. Sci. 2014, 148, 119-126. [CrossRef]

48. Zhu, K.; Kraemer, K.L.; Xu, S. The Process of Innovation Assimilation by Firms in Different Countries: A Technology Diffusion Perspective on E-Business. Manag. Sci. 2006, 52, 1557-1576. [CrossRef]

49. Salwani, M.I.; Marthandan, G.; Norzaidi, M.D.; Chong, S.C. E-commerce usage and business performance in the Malaysian tourism sector: Empirical analysis. Inf. Manag. Comput. Secur. 2009, 17, 166-185. [CrossRef]

50. DiMaggio, P.J.; Powell, W. The iron cage revisited: Institutional isomorphism and collective rationality in organizational fields. Am. Sociol. Rev. 1983, 48, 147-160. [CrossRef]

51. Prabowo, R.J.; Hidayanto, A.N.; Sandhyaduhita, P.I.; Azzahro, F.; Chairunnisa, A. The determinants of user's intention to adopt hyper-converged infrastructure technologies: An integrated approach. In Proceedings of the 2018 International Conference on Information Technology Systems and Innovation (ICITSI), Bandung/Padang, Indonesia, 22-25 October 2018.

52. Ghobakhloo, M.; Arias-Aranda, D.; Benitez-Amado, J. Adoption of e-commerce applications in SMEs. Ind. Manag. Data Syst. 2011, 111, 1238-1269. [CrossRef]

53. Alyamani, R.; Long, S. The Application of Fuzzy Analytic Hierarchy Process in Sustainable Project Selection. Sustainability 2020, 12, 8314. [CrossRef]

54. Ryu, H.; Ko, K.S. Sustainable Development of Fintech: Focused on Uncertainty and Perceived Quality Issues. Sustainability 2020, 12, 7669. [CrossRef]

55. Wibowo, S.; Deng, H. Multi-criteria group decision making for evaluating the performance of e-waste recycling programs under uncertainty. Waste Manag. 2015, 40, 127-135. [CrossRef] [PubMed]

56. Wibowo, S.; Grandhi, S. An innovative fuzzy-based multicriteria decision making method for evaluating the performance of electronic exam systems. Int. J. Eng. Educ. Life-Long Learn. 2018, 28, 130-155. [CrossRef]

57. Atanassov, K.; Gargov, G. Interval-valued intuitionistic fuzzy sets. Fuzzy Sets Syst. 1989, 31, 343-349. [CrossRef]

58. Xu, Z.; Gou, X. An overview of interval-valued intuitionistic fuzzy information aggregations and applications. Granul. Comput. 2017, 2, 13-39. [CrossRef]

59. Chhibber, A. View: India Needn't Worry About the 'Middle-Income Trap'. 2019. Available online: https://economictimes indiatimes.com/news/economy/policy/view-india-neednt-worry-about-a-middle-income-trap/articleshow/70283084.cms? from $=$ mdr (accessed on 1 March 2021).

60. Statista. Market Size of the Alternative Finance Industry in India from 2013 to 2018. 2021. Available online: https:/ / www.statista. com/statistics/883238/india-alternative-finance-market-size/ (accessed on 5 March 2021).

61. Narayan, P.K. An Assessment of the Indian Financial Services Sector; International Labour Office: Geneva, Switzerland, 2015. Available online: https:/ /www.ilo.org/wcmsp5/groups/public/---asia/---ro-bangkok/---ilo-jakarta/documents/meetingdocument/ wcms_396165.pdf (accessed on 5 March 2021).

62. India Brand Equity Foundation. Banking Sector in India. 2020. Available online: https://www.ibef.org/industry/banking-india aspx (accessed on 5 March 2021).

63. Khara, D. SBI: A Fintech Banker to Every India. 2021. Available online: https://timesofindia.indiatimes.com/blogs/voices/sbi-afintech-banker-to-every-indian/ (accessed on 6 March 2021). 
64. Business Standard. SBI Now Invests 3500 Crore in Technology Per Year; Releases 100+ New IT Initiatives. 2018. Available online: https: / / www.business-standard.com/article/news-ani/sbi-now-invests-3500-crore-in-technology-per-year-releases100-new-it-initiatives-118060900588_1.html (accessed on 6 March 2021).

65. Indrakumar, P. India's Banking Challenges in the Fintech Era, and the Role of Aussie Firms. 2017. Available online: https: / / tat.capital/India-s-banking-challenges-in-the-fintech-era-and-the-role-of-Aussie-firms.pdf (accessed on 10 January 2022).

66. State Bank of India. Embracing Technological Advancements, to Consolidate Our Digital Banking Leadership. 2021. Available online: https://bank.sbi/corporate/AR1718/2_Embracing\%20Technological\%20Advancements, \%20to \%20consolidate\%20our\% 20Digital\%20Banking\%20Leadership.html (accessed on 10 March 2021).

67. Avaloq. Avaloq: An NEC Company. 2021. Available online: https://www.avaloq.com/en/home (accessed on 10 March 2021).

68. Sopra Banking Software. Our Mission. 2021. Available online: https://www.soprabanking.com/\#null (accessed on 10 March 2021).

69. Fenergo. Client Lifecycle Management. 2021. Available online: https://www.fenergo.com/use-cases/digital-client-lifecyclemanagement/ (accessed on 11 March 2021).

70. Wang, W.; Liu, X. The multi-attribute decision making method based on interval-valued intuitionistic fuzzy Einstein hybrid weighted geometric operator. Comput. Math. Appl. 2013, 66, 1845-1856. [CrossRef]

71. Qi, X.; Liang, C.; Zhang, J. Generalized cross-entropy based group decision making with unknown expert and attribute weights under interval-valued intuitionistic fuzzy environment. Comput. Ind. Eng. 2015, 79, 52-64. [CrossRef]

72. Park, D.G.; Kwun, Y.C.; Park, J.H.; Park, I.Y. Correlation coefficient of interval-valued intuitionistic fuzzy sets and its application to multiple attribute group decision making problems. Math. Comput. Model. 2009, 50, 1279-1293. [CrossRef]

73. Chen, S.M.; Tsai, W.H. Multiple attribute decision making based on novel interval-valued intuitionistic fuzzy geometric averaging operators. Inf. Sci. 2016, 367, 1045-1065. [CrossRef] 